Valentina Vukmirović ${ }^{1}$, Dejan Petrović ${ }^{2}$ Milica Kostić-Stanković

${ }^{1} \mathrm{PhD}$ student, Faculty of Organizational Sciences, University of Belgrade

${ }^{2}$ Faculty of Organizational Sciences, University of Belgrade

\title{
Strategic Management and its Effects on Serbian Wood Industry
}

DOI: 10.7595/management.fon.2017.0027

\begin{abstract}
According to the available data on economic trends in Serbia, it is noticeable that companies in wood industry do not use their capacities to the maximum. Furthermore, a significant number of newly founded small enterprises, shortly after their establishment, go bankrupt or go into liquidation. Research works that have been conducted so far have indicated that, most commonly, company deterioration is caused by a lack of strategic approach in business management and company development. The aim of this paper is to gain an insight into the extent to which wood industry enterprises apply strategic approach (their vision, mission and development strategies) when making business decisions, as well as the effects of such approach. This will be achieved by analyzing collected questionnaires and interviews with competent experts from wood industry monitoring institutions. Besides, SWOT and PESTLE analyses of the surveyed companies will be conducted. Furthermore, possible solutions for overcoming weaknesses and threats emerging in Serbian wood industry development will be indicated. Likewise, the possibilities for encouraging industry development and increasing its competitiveness level will be presented.
\end{abstract}

Key words: strategic management, Serbian wood industry, SWOT, PESTLE, competitiveness.

JEL Classification: L10, L60, D81

\section{Introduction}

Primary wood processing and secondary furniture production are industry branches of strategic importance for creating gross domestic products, employment, exports etc. (Glavonjic et al., 2009). Serbia abounds in high quality forest resources which, supported by long tradition of wood processing, present significant developmental potential for numerous industrial sectors, as well as promotion of overall economic situation in Serbia. According to reports of Serbian Development Agency, direct foreign investments into wood industry amount to $€ 250$ million, accomplishing a growing surplus in terms of commodity exchange with foreign countries. (Forest based industry, 2016) However, studies indicate that the dynamics of wood industry development is not homogenous, which is best shown in the example of significant differences regarding the level of technological development, implementation of innovation, investment into development and research activities, applying knowledge and internationalization. (ID:WOOD, 2014) Additionally, the structure of wood industry production indicates that export of raw materials and semi-finished products dominate with over $70 \%$, while finished products, such as furniture, that, owing to quality raw materials and production technology could have much more important role by establishing premium prices, participate with less than $30 \%$. (Forest based industry, 2016) Also, imbalanced territorial distribution of production capacities often located remotely from the source of the raw materials, which largely increases transport costs, indicates that wood industry development is not considered strategically. Results of the research presented in this paper are in favor of this statement. 32 Serbian wood industry enterprises were surveyed. The research has indicated that domestic companies have access to high quality raw materials, are well-equipped technically, and have highly qualified and experienced staff. However, only a small number of them do business successfully. Therefore, the authors of this paper have attempted to provide the answer to the question of why the vast majority of domestic enterprises in wood and furniture industry are not competitive in domestic and foreign markets. The main assumption presented in this paper refers to the lack of strategic management concept in domestic enterprises as a primary issue in achieving competitive position in the market. In this paper, proposals on how to promote competitiveness of domestic enterprises based on the implementation of the clustering concept at the industry level, as well as the implementation of strategic management concept to the individual company level, will be elaborated. 


\section{Theoretical Framework - the Role of Vision, Mission and Strategic Planning in the Success of Entrepreneurial Venture}

Numerous authors (Chun and Davies, 2000; Mullane, 2002; Ingenhoff and Fuhrer, 2010) emphasize the importance of mission and vision as strategic tools in organization management, as well as in achieving specific goals such as maintaining and promoting competitive advantage, positioning and differentiating, and creating corporate identity and reputation. Peters (1997) claims that company can survive only if all of its employees are aware of the importance of a vision for the company's success, whereas Kotter (1996) puts emphasis on the motivational influence of a vision upon the employees. According to Dess et al. (2007), the vision can present the most important asset of an individual entrepreneur or organization. Wickham (2004) claims that vision transforms into target results by creating strategic aims which present the manager's statement that specific results will be accomplished in a given time period. Additionally, the author emphasizes that strategic aims are tightly related to the company's mission and vision and that these focus on values, market and customers that differentiate the company in relation to its competition.

While the vision represents a desired future position of the company (Ingenhoff and Fuhrer, 2010), the mission refers to organizational management current issues, such as existence purpose, competitiveness basis and competitive advantage. (Dess et al., 2007) Biloslavo and Lynn (2006) claim that mission statements are short documents in which purpose and function of a specific organization are expressed. Therefore, a mission statement is an organizational and cultural symbol, as well as a technical element of the organizational strategy. Flashaw et al. (2006) state the opinion given by strategic management theoreticians (Greenley, 1994; Sinha, 1990; Ramanujam and Venkatraman, 1987) who emphasize the positive association between strategic planning and company's business performances. According to the above mentioned authors, the key points of strategic management are mission creation and objectives setting, as well as implementation of strategies needed for accomplishing objectives and for their monitoring. Also, Flashaw et al. present us with Boyd's opinion (1991) who states that an effective system of strategic planning, which connects long-term strategic goals with middle-term and operational plans, enables organizations to achieve better results compared to competition that does not apply the process of strategic business planning.

Certain authors, such as Dermol (2012) share opinions expressed by other authors (Bart et al., 2001; Bartkus et al., 2000) who claim that managers consider a mission statement as one of the most important management tools. Furthermore, Dermol presents other authors' opinion (Musek Lesnik, 2008; Stallworth Williams, 2008) who claim that mission encourages strategy implementation, promotes organizational climate, external communication and company management. Moreover, Dermol (2012) directly relates the company's mission statement with its business success, taking financial results into particular consideration. Cambell et al. (2001) state that mission consists of five elements: business argumentation, corporate values, standards, behavior and strategy. Those five elements, if symbiotically related, can create a strong mission. Other authors emphasize that a carefully designed mission statement can be a key factor of strategic planning, as well as the starting point of a successful competitive strategy. (Fink and Kraus, 2009)

In exploring export strategies of forest products in the context of transition, Brodrechtova (2008) states that one of the greatest challenges which enterprises must cope with in domestic and especially foreign markets is environmental insecurity. This can be confirmed by Spetic et al. (2016) who discuss the critical factors of competitiveness for the British Columbia secondary wood products industry. The authors corroborate the opinion of Drejer (2002) and Harris and Twomey (2010) that strategic management has to result in solutions for adjusting to the "rapidly evolving, complex external environments and trends related to internationalization, technology, and sustainability" in addition to integrating strategic frameworks. This claim can be confirmed by Parobek et al. (2016) who state that globalization has affected all industries, including forest based industry as well. This implies that, in order to face international competition, "new strategies and advantages are required". Furthermore, Brodretchova (2008) quotes the opinions of other authors (Barney et al., 2001; Eisenhardt and Martin, 2000; Makadok, 2001) who claim that, in order to formulate and implement appropriate strategic solutions, companies must not only be in possession of resources and capabilities, but must have the knowledge of how to organize them.

Using a sample of 394 Slovene enterprises, Dermol (2012) established that having a clearly defined vision directly influences VAE (value added productivity per employee) indicator of company business performance. Amran (2012) cites research results of other authors (Rarick and Vion, 1995) who established that having a 
mission directly influences the increase in stockholder's equity, whereas Collins and Porras (1991), as well as Hamel (2009) determined that company mission has a very significant motivational effect on employees and influences the company competitiveness. Alawneh (2015) states other authors' opinion (Bart et. al, 1998), who emphasize the positive correlation between company mission and non-financial business indicators, whereas Sufi and Lyons (2003) perceived a strong influence of mission on financial results. Kim and Maubornge (2005) made a special contribution to analyzing mission and vision significance for the purpose of selection of appropriate strategies and strategic plans in creating new market space.

The above mentioned claims can be confirmed by the results of a scientific research conducted by Rajnoha et al. (2015), among 34 wood processing enterprises from Slovakia, which have indicated that the system of strategic performance management is an important tool for improving the overall business performance in Slovak wood-processing enterprises. Furthermore, Kauskale et al. (2016) conducted a research amongst wood manufacturing enterprises in Latvia that indicated that implementing strategic and tactic managerial decisions can lead to improvement in enterprise competitiveness. According to the results of Sthendahl and Roos (2008) empirical research conducted among wood industry enterprises in Sweden and Finland, the authors claim that the issue of increased competitive pressure from low-cost economies can be solved by developing and implementing new strategies which are focusing on product differentiation. Furthermore, Toivonen et al. (2005) conducted a research about the significance of intangible quality dimensions of Nordic wood industry in the German market. The results of the research indicated that by enhancing their intangible assets, Nordic wood industry companies could improve their competitive position in the observed market.

Bearing in mind all the above mentioned claims, the authors of this paper conducted a research among Serbian wood industry enterprises, regarding the significance of strategic management in achieving preferable business results as well as improving their competitive position in local and foreign markets. The research was conducted in order to obtain an insight on the impact of strategic management tools, such as vision, mission, strategic plans and objectives on business results and competitiveness of domestic enterprises. The results and conclusions of this research will be presented in the following sections of this paper.

\section{A Brief Overview of Wood Based Industry in Serbia}

According to the results of the research conducted by Glavonjic et al. (2016) presented in the Action plan for support to Serbian wood industry, at the end of 2014., 2,540 enterprises were active in Serbian wood industry. Within this number, 1,786 enterprises were engaged in wood processing, while 754 enterprises were engaged in furniture production. The majority of enterprises in the segment of wood processing, 668 of them, were engaged in the production of sawn wood, followed by 434 enterprises engaged in the production of joinery. Among enterprises engaged in furniture production, 419 produce other furniture, followed by 199 enterprises producing office furniture and 106 enterprises producing kitchen furniture. In the structure of wood processing and furniture production enterprises, micro and small enterprises are most numerous, while medium and large enterprises participate with 3 and 5 percent in overall structures. The authors of the Action plan suggest that this structure is rather unfavorable in terms of export competitiveness and positioning in foreign markets.

According to the statistical yearbook of the Republic of Serbia from 2016, the total number of employees in Serbian wood industry in 2015 amounted to 22,711. Considering the research conducted by Vasiljevic (2015), it can be concluded that territorial distribution of wood processing enterprises is not in accordance with availability of wood raw materials. The results of the research have indicated that the largest number of enterprises and employees (37.1\%) in wood industry are concentrated in the city area of Belgrade, even though its afforested area totals in $2.3 \%$ of the overall afforested areas in Serbia. On the other hand, in the regions of South and Eastern Serbia which total $46 \%$ of afforested areas, only $13.6 \%$ of wood industry employees were concentrated. According to the data provided by the Statistical Office of the Republic of Serbia in 2016, the overall achieved operating income of companies and entrepreneurs in the wood industry of Serbia in 2014 amounted to $€ 787$ million. According to Glavonjic et al. (2016), even though the number of enterprises engaged in furniture production is 2.3 times smaller than the number of wood processing enterprises, their generated revenues are almost equal to the operating income of enterprises engaged in wood processing activities. This piece of information can lead us to a conclusion that domestic wood industry enterprises should focus on producing products with high added value rather than on export of raw materials. 


\section{Results of the Research}

\subsection{Research Methodology}

Simple random sampling was used to create a study sample in this research. The enterprises that took part in this research were randomly selected from The Serbian Business Registers Agency (SBRA) business entities database. Nevertheless, the study sample was created in order to include enterprises of different sizes (micro, small, medium and large) from different regions of Serbia, and from different wood processing sectors. In order to conduct the research in this paper, the authors created a questionnaire that consisted of 17 close-ended and open-ended questions. The questionnaire was created in order to provide an insight into strategic management policies amongst Serbian wood processing enterprises. The research questions scope included inquiries about enterprises' attitude towards creating and implementing strategic management elements to their business practice, such as creating a mission, vision, strategic plans and aims, development and action plans, competitive strategies as well as questions related to strategic units responsible for their implementation. Furthermore, research questions adressed enterprises representatives' attitude towards main strengths and weaknesses of their business, as well as towards external opportunities and threats based on which a SWOT analysis was created. Likewise, the research participants were asked about their opinions on political, economic, sociocultural, technological, legislative and environmental issues related to their business in order to realize development potentials and methods for removing obstacles towards achieving business development and growth. The results of this part of the questionnaire were presented in a form of PESTLE analysis.

In this research, 60 questionnaires were forwarded electronically during October-November 2016, while 14 questionnaires were delivered directly during the Belgrade Furniture Fair in November 2016. The response rate was $48.65 \%$ - 36 out of 74 enterprises completed the questionnaires. Out of 36 completed questionnaires, 4 were only partially completed and were not taken into consideration. The remaining 32 fully completed questionnaires were analyzed. Descriptive and analytical statistical methods were used in this study. Absolute and relative numbers $(n, \%)$ were used in the descriptive analysis. For the analysis of the differences in frequencies, analytical statistical methods - Fisher's exact test and chi-squared test, were used. All data were analyzed using the IBM SPSS Statistics 22 (IBM Corporation, Armonk, NY, USA) software package. Statistical hypotheses were tested at the level of statistical significance (alpha level) of 0.05.The results were tabulated and graphically presented. Based on the research results, the authors proposed a possible solution to enhancing domestic furniture based industry competitiveness and provided implications for further research.

\subsection{Surveying the Enterprises}

Observing the enterprises according to their size, 19 of the analyzed enterprises (59.4\%) belong to the group of micro and small enterprises, whereas the remaining 13 are medium-sized or large enterprises (40.6\%). According to the type of activity they perform, enterprises were divided into four categories: furniture production - 13 companies (40.6\%), production and sales - 13 companies (40.6\%), parquetry and joinery production -4 companies (12.5\%), production, engineering and designing - 2 companies (6.3\%).

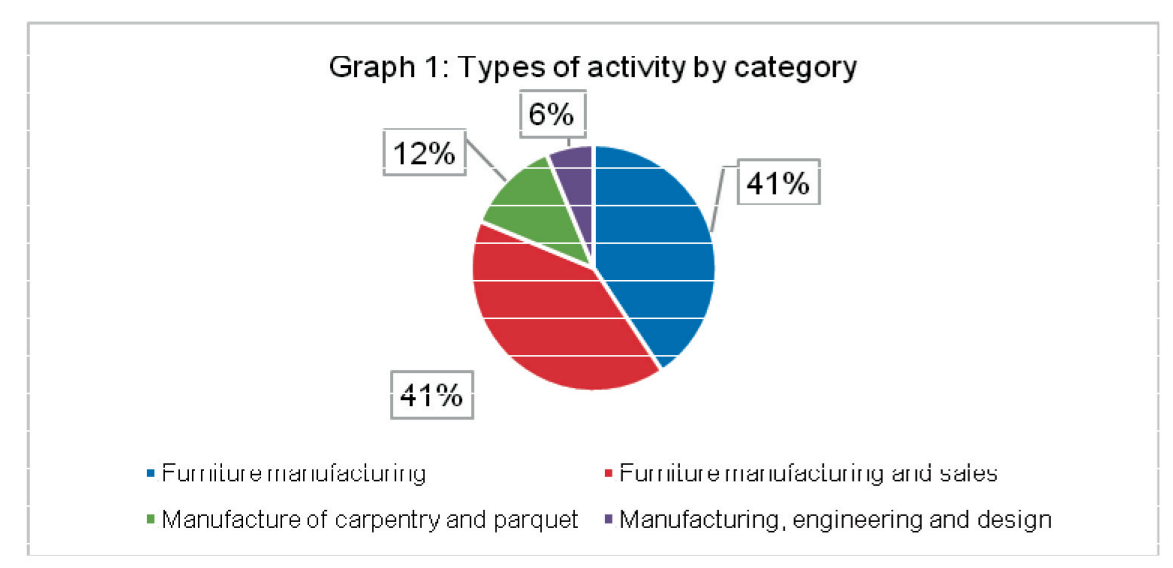

Picture 1: Types of activity by category (Source: Authors' research) 
Taking into consideration the region in which enterprises perform their activities, the largest number of surveyed enterprises are from: Vojvodina - 9 companies (28.1\%), Central Serbia - 7 companies (15.6\%), Southern Serbia - 4 companies (12.5\%), City of Belgrade -3 companies (9.4\%), Eastern Serbia -2 companies (6.3\%) and Sandžak - 2 companies (6.3\%).

Table 1: Strategic categories according to the size of the enterprise

\begin{tabular}{|l|l|l|l|l|l|}
\hline \multicolumn{5}{|c|}{ Micro and small enterprises } & Medium and large enterprises \\
\hline & $\mathbf{N}$ & $\%$ & $\mathbf{n}$ & $\%$ & p-value \\
\hline $\begin{array}{l}\text { Enterprise } \\
\text { characteristics }\end{array}$ & \multicolumn{5}{|l|}{} \\
\hline Mission & 0 & 0.0 & 7 & 53.8 & 0.001 \\
\hline Vision & 0 & 0.0 & 8 & 61.5 & $<0.001$ \\
\hline $\begin{array}{l}\text { Development } \\
\text { strategies }\end{array}$ & 12 & 63.2 & 12 & 92.3 & 0.101 \\
\hline $\begin{array}{l}\text { Strategic plans and } \\
\text { strategic aims }\end{array}$ & 5 & 26.3 & 12 & 92.3 & $<0.001$ \\
\hline Action plan & 2 & 10.5 & 11 & 84.6 & $<0.001$ \\
\hline $\begin{array}{l}\text { Development } \\
\text { project }\end{array}$ & 18 & 94.7 & 13 & 100 & 0.408 \\
\hline $\begin{array}{l}\text { Strategic project } \\
\text { organizational unit }\end{array}$ & 1 & 5.3 & 6 & 42.6 & $<0.05$ \\
\hline
\end{tabular}

(Source: Authors' research)

The table presented above summarizes the attitudes of interviewed enterprises about implementing strategic management documents in their business processes. As it can be observed, not a single micro or small-sized enterprise had a clearly defined mission (0.0\%), while $53.8 \%$ of medium-sized and large enterprises had a mission, which is a significant difference, viewed statistically $(p<0,001)$. This points to the fact that entrepreneurs establish small enterprises without market research and strategy creation for their further development. Entrepreneurs mainly start small-sized enterprises by taking the existing small enterprises from wood processing industry as role models, which negatively reflects on their further development opportunities. When it comes to medium and large enterprises, the situation is much more favorable. Most medium enterprises have grown from small enterprises due to clearly defined mission, vision, strategy and strategic development plans. Regarding a clearly defined development strategy for individual sectors, important differences between micro and small enterprises, on one side, and medium and large enterprises, on the other, have been noticed. 63.2\% of small and micro companies and $92.3 \%$ of medium and large enterprises had a clearly defined strategy.

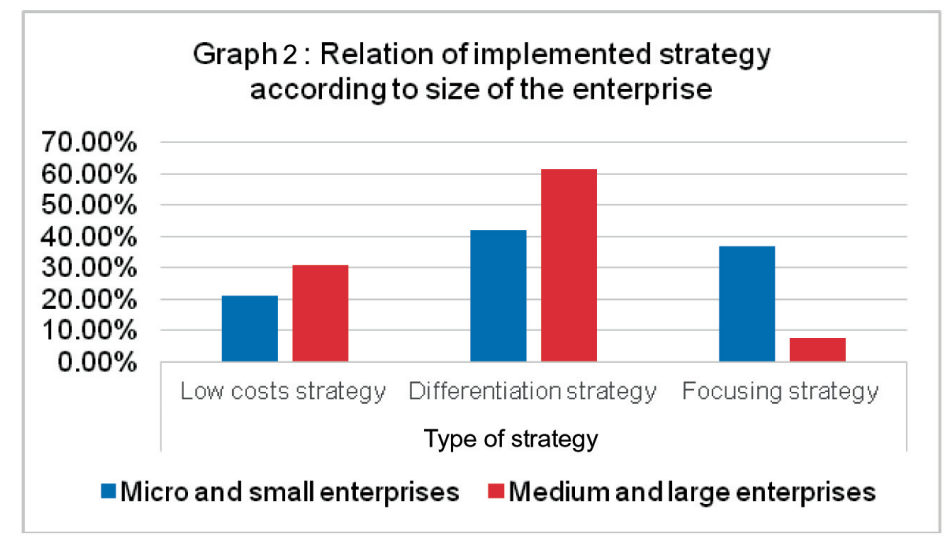

Picture 2: Relation of implemented strategy according to size of the enterprise

(Source: Authors' research)

The results of the responses to the question on whether surveyed enterprises develop competitive strategies, as a strategic method of distinguishing their offer from competitors and creating a sustainable market niche, indicate that the largest percentage of micro and small enterprises $(42.1 \%)$ as well as medium and large enterprises $(61.5 \%)$ opt for the differentiation strategy. When it comes to the focusing strategy, the situation is reversed. $42.1 \%$ of small enterprises and only $7.7 \%$ of the large enterprises apply the focusing strategy. Small enterprises are mostly focused on lower level of wood processing, i.e., producing semi-finished 
products, which results in lower employment and achieving less value added and hence lower profitability of the company. $26.3 \%$ of small and micro enterprises and $92.3 \%$ of medium and large enterprises had a clearly defined strategic plan and strategic objectives, which is a significant difference, viewed statistically $(p<0,001)$. Therefore, the largest number of large enterprises have strategic plans that help them achieve long-term objectives in accordance with their vision statement, whereas small enterprises that do not have a vision, most commonly do not have a strategic plan either.

$10.5 \%$ of micro or small enterprises and $92.3 \%$ of medium and large enterprises had defined action plans, which is a significant difference statistically $(p<0,001) .94 .7 \%$ of micro or small and $100 \%$ of medium and large enterprises defined their development projects. The existence of an organizational unit dealing with the realization of strategic projects has been noted in $5.3 \%$ of micro or small and $46.2 \%$ medium and large enterprises, which is a significant difference statistically $(p<0,05)$. Large enterprises with organizational units that deal with strategic projects realization, have 7 times larger percentage share in the structure of interviewed enterprises in comparison with small enterprises. These enterprises apply good practice of contemporary enterprises from developed countries, which consists of efficient cooperation between internal organizational units. (Logan, Stokes, 2003)

With the aim of performing a deeper and more complex analysis of the role and significance of strategic approach to enterprise development, a connection and mutual influence of key factors in the enterprises (SWOT analysis) as well as influence of external factors on enterprises in wood industry (PESTLE analysis) have been established. Some of the most important issues which provide us with additional insight into the state of wood industry and possibilities for its further development are presented below:

- $70.8 \%$ of enterprises with a defined vision also have strategic plan and strategic aims, and $29.2 \%$ have no clearly defined vision, nor the strategic plan and strategic objectives.

- $38.6 \%$ of enterprises with clearly defined vision apply a low cost strategy, $35.3 \%$ apply a differentiation strategy, whereas $26.1 \%$ use focusing as their competitive strategy.

- $74.2 \%$ of the enterprises which have an organizational unit for strategic projects have achieved business results in accordance with their business objectives, while $25.7 \%$ of the interviewed enterprises do not have an organizational unit dealing with strategic projects.

- Out of $64.2 \%$ of enterprises that perceive inadequate technology as a major weakness, $15.4 \%$ consider the availability of high quality raw materials as their biggest advantage and remain at the lower level of wood production.

- From a total of surveyed enterprises, $28.2 \%$ considered lack of competitiveness to foreign products as a main threat to sustainable business, while $21.6 \%$ of them considered availability of raw materials as their greatest strength.

- $70.3 \%$ of surveyed enterprises that did not have a vision and a development strategy, claimed that most of their business problems would be solved by independent appearance in foreign markets with significant financial support from the state. Only a small number of enterprises realizes that state authorities have no such ability and seek for business problems solving in creating clusters, i.e., creating common technical services and costs share as in developed countries (Bouman, 2003) as well as certain developing countries such as Chile, Bolivia and Columbia, which implement the Porter clustering model. (Porter, 2007)

\section{SWOT Analysis of the Surveyed Enterprises}

In order to uncover the opportunities that surveyed enterprises could exploit and point out to their weaknesses and external threats that should be forestalled in order to achieve business growth, the authors of this paper created a SWOT analysis. The analysis was created based on the questionnaire answers that referred to interviewed enterprises' perception of their internal advantages and drawbacks, as well as external opportunities and threats. As it can be seen in Table 2 presented below, domestic enterprises have mostly recognized the availability of high-quality raw materials as their advantage, which cannot be the base for sustainable competitive strategy. On the other hand, high costs of production that can be related to the inadequate technology implemented are seen as a major drawback, which implies that surveyed enterprises should focus on implementing development strategies whose main aim is to encourage improvement of technological processes through innovations. Nevertheless, the lack of strategic orientation on both internal and external level was seen as one of the main drawbacks, which has confirmed the authors' presumptions that strategic management improvement is the basis for business improvement at the enterprise as well as at the industry level. 
Table 2: SWOT analysis

\begin{tabular}{|c|c|}
\hline Strong points - What are our advantages? & Weak points - What are our drawbacks? \\
\hline $\begin{array}{l}\text { - } \quad \text { Raw materials availability } \\
\text { - } \quad \text { Professional staff } \\
\text { - } \quad \text { Production processes } \\
\text { - Technical equipment }\end{array}$ & $\begin{array}{l}\text { - } \quad \text { High production costs } \\
\text { - } \quad \text { Inades issues } \\
\text { - } \quad \text { Slow approach to new markets } \\
\text { - } \quad \text { Lack of strategic orientation } \\
\text { Insufficient level of competitiveness }\end{array}$ \\
\hline Opportunities - What can we use? & Threats - What can jeopardize us? \\
\hline $\begin{array}{ll}\text { - } & \text { Foreign investments } \\
\text { - } & \text { Business partnerships } \\
\text { - } & \text { Participation in foreign markets } \\
\text { - Outsourcing and cooperation }\end{array}$ & $\begin{array}{l}\text { - } \quad \text { Purchasing power } \\
\text { - } \quad \text { Organizational climate } \\
\text { - } \quad \text { Lack of strategic orientation at industry level } \\
\text { Insufficient support from local and state } \\
\text { authorities }\end{array}$ \\
\hline
\end{tabular}

(Source: Authors' research)

\subsection{Interviewing the Experts}

Besides interviewing wood industry enterprises representatives, experts from five public institutions that are competent for wood based industry development were interviewed. Those were: Serbian Chamber of Commerce, Vojvodina Chamber of Commerce, Agency for Wood, Wood industry cluster and the Faculty of Forestry at the University of Belgrade. Experts interviewing was conducted using the same questionnaire which was delivered to the companies with the aim of obtaining and comparing their answers to the answers obtained from enterprises' management. The interviewed experts agreed on a number of claims, such as: 1) only a small number of wood industry enterprises (mainly large enterprises) have clearly defined vision, mission and development strategy; 2) enterprises that have clearly defined vision, mission and development strategy develop much more dynamically than those that have not; 3) small enterprises should be encouraged to cluster and thus increase their competitive ability in domestic and foreign markets; 4) processing capacities should be located near the sources of raw materials as much as possible; 5 ) the wood processing sector deserves a larger social significance and financial support; 6) non-material assets (design, quality, service, innovation, software, brand etc.) should be more prominently emphasized in furniture production activities. Based on the data collected from interviewing public institutions representatives as well as desk research which included analyzing strategies and action plans for developing Serbian forest based industry, the authors of this paper created a PESTLE analysis. The aim of this analysis was to provide an insight into the external forces that influence the wood processing industry and the enterprises of this sector, since tracking changes in the environment is necessary for providing an adequate response to them. Furthermore, before making a proposal on possible development strategies, which was presented in the following part of this paper, authors had to provide a situational analysis on which the proposal would be based.

Table 3: PESTLE analysis

\begin{tabular}{|c|c|}
\hline Examination of environmental impact & Structural analysis of competitive environment \\
\hline Political & $\begin{array}{l}\text { - } \quad \text { Shared competence of regulatory bodies } \\
\text { - Insufficient recognition of the importance of wood } \\
\text { processing industry for development of rural areas } \\
\text { - Inefficient resolution of remaining issues of privatization } \\
\text { - } \quad \text { Complicated procedures and inefficient administration }\end{array}$ \\
\hline Economic & $\begin{array}{l}\text { - Insufficient activity of economic ambassadors } \\
\text { - Lack of adequate export stimuli } \\
\text { - Unfair competition ("grey economy" dumping pricing of } \\
\text { imports) } \\
\text { - Unfavorable loans } \\
\text { - Heavy fiscal and parafiscal burdens } \\
\end{array}$ \\
\hline Socio-Cultural & $\begin{array}{l}\text { - Problem with collection of receivables } \\
\text { - Negative impact of national culture on development of } \\
\text { organizational culture } \\
\text { - Poor cooperation between enterprises and scientific or } \\
\text { educational institutions } \\
\text { - Poor cooperation between public institutions and } \\
\text { entrepreneurs (impoliteness, lack of transparency) }\end{array}$ \\
\hline Technological & $\begin{array}{l}\text { - Substituting wood with other materials } \\
\text { - Inadequate knowledge transfer } \\
\text { - Slow development of technological infrastructure } \\
\text { (science and technology parks, innovation centers, } \\
\text { clusters) }\end{array}$ \\
\hline
\end{tabular}




\begin{tabular}{|c|c|}
\hline Examination of environmental impact & Structural analysis of competitive environment \\
\hline Legislative & 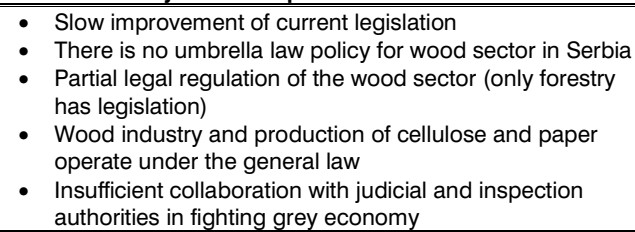 \\
\hline Environmental & $\begin{array}{l}\text { - Irrational wood consumption } \\
\text { - Endangerment of forest resources due to pollution and } \\
\text { diseases } \\
\text { - } \text { Failure in implementing strategies of afforestation } \\
\text { - Lack of recycling strategies }\end{array}$ \\
\hline
\end{tabular}

(Source: Authors' research)

\section{Development of strategic management and clustering as a solution for promoting competitiveness of wood processing industry in Serbia}

Some authors claim that Serbian industrial enterprises' products are not competitive, neither by price nor by quality, which has limiting influence on export augmentation as a consequence. (Jugovic, Jasko, 2015) Furthermore, authors hold the view that characteristics of industrial development in Serbia are a clear indicator of industry crisis, neglect of its development, low level of competitiveness, modest exports and unfavorable technological structure. Therefore, the authors stress the need for clusters development as a factor of contribution to the enhancement of productivity and specialization, added value creation, increase in innovation which results in competitive advantage promotion of individual enterprises, industry sectors, as well as the overall industry. This can be confirmed by reports of European Union institutions, which indicate that the economic activity located within clusters results in over $39 \%$ of overall employment and $55 \%$ of overall revenue at the European level. Additionally, the significance of clusters for the European market is illustrated by the following facts: business activities within clusters result in $87 \%$ of all patents, they achieve a higher level of productivity and increase in productivity rate, ensure higher salaries for the employees, as much as $11 \%$ higher when compared to business activities outside clusters, noting that their potential growth is not conditioned by the size of the local market. (Smart Guide to Cluster Policy, 2016)

Furthermore, in paper on the typology for the strategic moves of the Finnish forest based industry, Rusko (2011) elaborates that the main characteristic of Finnish forest based industry is the production of low value added products on small domestic markets. The author adds that this sort of economic challenges increases the importance of introducing strategic decision making processes in order to improve the situation in Finnish forest based industry. Therefore, the author proposes the implementation of the coopetition concept among companies, with the aim of creating greater value and improving firm performances through mutual cooperation and competition. Since Serbian forest based industry is predominantly focused on small domestic or regional market and mostly produces low value added products, this concept could possibly be a good solution to improving its competitive position in both local and global markets.

Despite these recommendations, the results of the research conducted in this paper indicate that domestic enterprises show insufficient willingness for mutual cooperation and collaboration in participation in both domestic and foreign markets. Instead of linking in clusters, the interviewed enterprises prefer independent participation in foreign markets, even though very few of them possess necessary resources and capacities to perform such activities.

The research indicated that, due to meager purchasing power of the native population, a significant number of enterprises is focused on implementing low cost strategies, due to lack of financial means. The low cost strategy directly influences the possibility of developing product design activities, which makes their products uncompetitive in local and foreign markets. Even though majority of enterprises included in this research claimed that they apply differentiation strategy, unfavorable sales figures indicate that enterprises are not familiar with market needs. Furthermore, the results of the research indicated that domestic enterprises are mostly focused on production in large series. Most of the interviewed enterprises are not specialized in any certain type of production activity, but tend to produce numerous sorts of furniture. Instead, the authors of this paper suggest that domestic enterprises could achieve a better competitive position through orienting 
towards specialized production, high quality furniture production in optimal series, greater flexibility in adjustments to market changes, investment into production development, particularly into product design improvement, with the aim of retaining their position in the existing markets and entering new ones.

\section{Conslusion}

This paper investigated the impact and significance of the strategic approach to business activities in domestic wood based industry enterprises with the aim of promoting their competitiveness. The results of the research conducted in this paper implied that domestic entrepreneurs insufficiently apply strategic tools in business operations, which results in unconformity of production program to local and foreign market needs. Furthermore, the authors noticed that the main reasons for an unsatisfactory competitiveness level of Serbian wood industry can be classified in four groups: a) production fragmentation and insufficient connection between producers, b) insufficient recognition of wood products exported from Serbia, c) institutional disorganization which is a consequence of lack of clear strategy for wood industry development, d) technological development, production modernization and investments are slow and insufficient. Therefore, the authors proposed enterprises clustering as well as change of focus from raw materials export, as a primary activity, to manufacturing high added value products as possible manners in which competitiveness of domestic wood industry could be enhanced. The study limitations of the empirical research in this paper have to be taken into consideration before interpreting its results. The limitations refer to possible subjectivity of interviewed enterprises' management representatives as well as the experts in the field, lack of external ideas due to closed circle and study sample which was created by random selection. Nevertheless, with the support of results presented in this paper, obtained by empirical and desk research, other researchers should be encouraged to provide more detailed studies on the strategic development of individual sectors amongst wood industry enterprises. This implies that special attention should be paid to developing strategic plans for marketing, research and development and product design activities in domestic enterprises in order to enable production of contemporary programs of specialized products. Furthermore, bearing in mind the significance of this industry for the economic growth of Serbia, the authors emphasized the need for identifying and removing obstacles for its sustainable development as well as proposing new solutions for improvement of its competitive position. Amongst other, this implies focusing on emerging markets and strategic adjustment of production to market needs.

\section{REFERENCES}

[1] Adizes, I. (2011). Insights on management. Santa Barbara, California, USA: Adizes Insititute Publications.

[2] Alawneh, A. A. (2015). The Impact of Mission Statement on Performance: An Exploratory Study in the Jordanian Banking Industry. Journal of Management Policy and Practice, 16(4), 73-87. Retrieved from: http://www.na-businesspress.com/JMPP/AlawnehAA Web16_4_pdf.

[3] Amran, N. A. (2012). Mission statement and company performance: Evidence from Malasyia. International journal of business and behavioral sciences, 2(4), 98-107. Retrieved from:.

[4] Barney, J., Wright, M., Ketchen Jr., D.J., 2001. The resource-based view of thefirm: ten years after 1991. Journal of Management 27, 625-641, in Brodretchova, Y. (2008). Determinants of export marketing strategies of forest products companies in the context of transition - The case of Slovakia. Forest Policy and Economics, 10. 450-459. doi:10.1016/j.forpol.2007.12.004.

[5] Biloslavo, R., Lynn, M. (2006). Mission statements in Slovene enterprises - Institutional pressures and contextual adaptation. Management Decision, 45(4), 773-788. DOI 10.1108/00251740710746024.

[6] Bouman, K. (2003). Strategija u praksi. Novi Sad: Prometej.

[7] Brodretchova, Y. (2008). Determinants of export marketing strategies of forest products companies in the context of transition - The case of Slovakia. Forest Policy and Economics, 10. 450-459. doi:10.1016/j.forpol.2007.12.004

[8] Campbell, D., Shrives, P., Bohmbach - Saager, H. (2001). Voluntary Disclosure of Mission Statements in Corporate Annual Reports: Signaling What and To Whom? Business and Society Review, 106(1), 6587.DOI: 10.1111/0045-3609.00102.

[9] Chun, R., Davies, G. (2001). E-reputation: The role of mission and vision statements in positioning strategy. Journal of Brand Management, 8(4) 315-333. DOI: .

[10] Dermol, V. (2012). Relationship between mission statement and company performance. Scientific Annals of the „Alexandru loan Cuza” University of laşi Economic Sciences. 59 (1), 321-336. DOI 10.2478/v10316-012-0022-9. 
[11] Dess, G.G., Lumpkin, G.T., Eisner, A.B. (2007). Strategijski menadžment. Beograd: Data status.

[12] Drejer, A. (2002). Strategic management and core competencies: theory and applications, Westport, CT, pp. 264. in Spetic, W.C., Kozak, R.A., Vidal, N.G. (2016). Critical factors of competitiveness for the British Columbia secondary wood products industry. BioProducts Business 1(2), pp. 13-31.

[13] Eisenhardt, K.M., Martin, J.A., 2000. Dynamic capabilities: what are they? Strategic Management Journal 21, 1105 - 1121. retrieved from:http://mail.im.tku.edu.tw/ myday/teaching/992/SEC/S/992SEC _T3_Paper_20100415_Eisenhardt\%20Martin\%20(2000)\%20\%20Dynamic\%20capabilities\%20what\%20a re\%20they.pdf in Brodretchova, Y. (2008). Determinants of export marketing strategies of forest products companies in the context of transition - The case of Slovakia. Forest Policy and Economics, 10. 450459. doi:10.1016/j.forpol.2007.12.004.

[14] Falshaw, R.J., Glaister, K.W., Tatoglu, E. (2006). Evidence on formal strategic planning and company performance. Management Decision, 44(1), 9-30. DOI 10.1108/00251740610641436.

[15] Forest based industry. (2016). Development Agency of Serbia (RAS). Retrieved from: http://ras.gov.rs/uploads/2016/11/sector-fbi.pdf.

[16] Fink, M., Kraus, S., (2009). The Management of Small and Medium Enterprises. New York: Routledge.

[17] Glavonjic B.; Vlosky R.P.; Borlea G. F.; Petrovic S.; Sretenovic P. (2009). The Wood Products Industry in the Western Balkan Region. Forest products journal, 59, 98-111. DOI: 10.13073/0015-7473-59.10.98.

[18] Glavonjic, B., Baron, J., Dundjerovic, T., Pavlovic-Krizanic, T. (2016). Akcioni plan podrške drvnoj industriji Srbije u izvozu proizvoda sa visokom dodatom vrednošću. Kancelarija Ujedinjenih nacija za projektne usluge (UNOPS).

[19] Guidebook Series, How to support SME Policy from Structural Funds. Smart Guide to Cluster Policy. European Commission Directorate General for Internal Market, Industry, Entrepreneurship and SMEs Unit F.2: Clusters, Social Economy and Entrepreneurship. European Union, 2016.

[20] Hamel, G. (2009). The Future of Management. Boston, Massachusets: Harvard Bussines Review Press.

[21] Harris, D. L. and Twomey, D. F. (2010). The enterprise perspective: a new mind-set for competitiveness and sustainability. Competitiveness Review, 20 (3), 258-266. in Spetic, W.C., Kozak, R.A., Vidal, N.G. (2016). Critical factors of competitiveness for the British Columbia secondary wood products industry. BioProducts Business, 1(2), 13-31.

[22] Ingenhoff, D., \& Fuhrer, T. (2010). Positioning and differentiation by using brand personality attributes: Do mission and vision statements contribute to building a unique corporate identity?. Corporate Communications: An International Journal, 15(1), 83-101.

[23] ID: WOOD Interesno povezivanje znanja, inovacija I dizajna u drvoprerađivačkom sektoru Jugoistočne Evrope. Tematski Dosije br.3 - Klasteri. (2014). Retrieved from: http://www.nerda.ba/pdf/IDWOOD_tematski_dosije_Klasteri.pdf.

[24] Mullane, J. V. (2002). The mission statement is a strategic tool: when used properly. Management Decision, 40(5), 448-455.

[25] Jugovic, T., Jasko, O. (2015). Cluster as essential formation of economic development. X skup privrednika i naučnika SPIN'15. Inovativna rešenja operacionog menadžmenta za revitalizaciju privrede Srbije. 362-368. Retrieved from: http://spin.fon.bg.ac.rs/wp-content/uploads/2015/11/SPIN15_bornik radova Proceedings.pdf.

[26] Kauskale, L., Fedotova, K., Geipele, S. (2016). The Strategic Management Analysis of Wood Manufacturing Companies in Latvia - Interdisciplinary approach. Proceedings - International Conference on Industrial Engineering and Operations Management. 1114-1121. Retrieved from: .

[27] Kim, Ch, Mauborgne, R, (2005). Blue Ocean Strategy. Boston, Massachusets: Harvard Bussines Press.

[28] Kotter, J. (1996). Leading change. Boston, Massachusets: Harvard Business School Press.

[29] Logan, R., Stokes, L., (2003). Collaborate to Compete. Toronto: Wiley.

[30] Makadok, R., 2001. Toward a synthesis of the resource-based and dynamic capability views of rent creation. Strategic Management Journal 22, 387-401.DOI: 10.1002/smj.158 in Brodretchova, Y. (2008). Determinants of export marketing strategies of forest products companies in the context of transition The case of Slovakia. Forest Policy and Economics, 10. 450-459. doi:10.1016/j.forpol.2007.12.004.

[31] Peters, T. (1997). Thriving on chaos: Handbook for a management revolution. New York, Knopf.

[32] Parobek, J., Palus, H., Loucanova, E., Kalamarova, M., Glavonjic, B. (2016). Competitiveness of Central European countries in the EU forest products market with the emphasis on Slovakia. ActaFacultatis Xylologiae Zvolen. 58(1). 125-136. DOI: 10.17423/afx.2016.58.1.14

[33] Rajnoha, R., Lorincová, S., Bego, M. (2015). Strategic Business Performance Management System in Wood Processing Industry in Slovakia. Drvna industrija, 66(2), 137-146.doi:10.5552/drind.2015.1504.

[34] Rusko, R. (2011). Exploring the concept of coopetition: A typology for the strategic moves of the Finnish 
forest industry. Industrial Marketing Management. 40. 311-320. doi:10.1016/j.indmarman.2010.10.002.

[35] Serbian Business Registers Agency. (2016). Internal reports. Retrieved from:http://ras.gov.rs/uploads/2016/11/sector-fbi.pdf.

[36] Statistical yearbook of the Republic of Serbia. (2016). Statistical office of the republic of Serbia. Retrieved from: http://pod2.stat.gov.rs/ObjavljenePublikacije/G2016/pdf/G20162019.pdf.

[37] Stendahl, M., Roos, A. (2008). Antecedents and Barriers to Product Innovation - a Comparison between Innovating and Non-Innovating Strategic Business Units in the Wood Industry. Silva Fennica 42(4) The Finnish Society of Forest Science - The Finnish Forest Research Institute, 659-681. Retrieved from: http://www.metla.fi/silvafennica/full/sf42/sf424659.pdf.

[38] Toivonen, R., Hansen, E., Järvinen, E., Enroth, R. (2005). The Competitive Position of the Nordic Wood Industry in Germany - Intangible Quality Dimensions. Silva Fennica, 39(2), 277-287. Retrieved from: http://www.metla.fi/silvafennica/full/sf39/sf392277.pdf.

[39] Vasiljevic A.: Uticaj tržišta drveta na socio-ekonomsku komponentu održivog razvoja drvnog sektora u Srbiji, doktorska disertacija, Univezitet u Beogradu - Šumarski fakultet, Beograd, 2015.

[40] Wickham, P.A. (2004). Strategic entrepreneurship, 3rd Ed. Harlow, England: Prentice Hall.

Received: 2017-02-08

Accepted: 2017-09-27

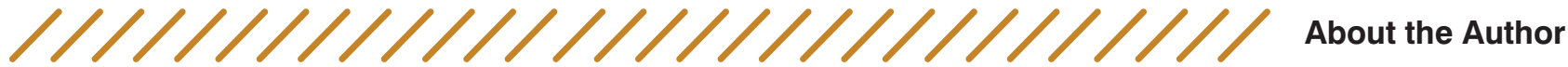

\section{Valentina Vukmirović \\ University of Belgrade, Faculty of Organizational Sciences}

MSc Valentina Vukmirović is a PhD student at the Faculty of Organizational Sciences.

She has published numerous papers in refereed journals and participated in many scientific conferences in the country and abroad. Her research interests include marketing management, brand management and visual communications.

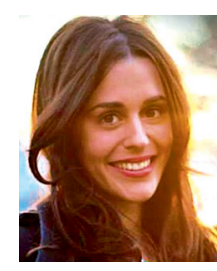

Dejan Petrović
University of Belgrade, Faculty of Organizational Sciences, Serbia

Dr. Dejan Petrović is a full professor and Head of Department of Management and specialized management disciplines at the Faculty of Organizational Sciences,

University of Belgrade. He is also a visiting professor at several universities in the country and abroad. His research interests include management, project management, strategic management, project appraisal and change management. He has been a consultant for a wide variety of public and private organizations, and has published books and articles in refereed journals.

\section{Milica Kostić-Stanković \\ University of Belgrade, Faculty of Organizational Sciences, Serbia}

Dr. Milica Kostić-Stanković is a full professor and Head of Department of Marketing management and Public Relations. She is also a visiting professor at several universities in the country and abroad. Her research interests include marketing management, public relations and business communication. She has been a consultant for a wide variety of public and private organizations, and has published books, practicums and articles in

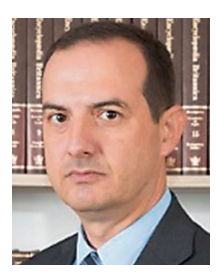
refereed journals. She is a winner of numerous awards and honors in Serbia and abroad. 